\section{Diary of Societies.}

\section{THURSDAY, DECEMBer 15.}

Royal Society of Yedicine (Dermatology Section), at 4.30.-Major A. E. Milner: Diathermy in the Treatment of Lupus Erythematosus.

Linnean. Society of London, at 5.-Prof. G. C. Bourne: The Raninidæ, a Group of Crustacea.-F. A. Potts: Narrative of the Carnegie Institution Expedition to Samoa.

NEwCOMEN Socrety (at King's College, Strand, W.C.2), at 5.-Annual General Meeting.-At 5.15.-R. C. S. Walters: Greek and Roman Engineering Instruments.

roman Mathematical Societr (at Royal Astronomical Society), at 5. -J. H. Jeans: The New Dynamics of the Quantum Theory (Lec. J. H. Jeans: The New Dynamics of the Quantum Theory (Lec-
ture). The following papers will be taken as read:- W. P. Milne: ture) The following papers will be taken as read :-W. P. Milne : The Relations Between Apolarity and Clebsch's Mapping of the
Cubic Surface in a Plane.-Miss G. D. Sadd: Certain Types Cubic Surface in a Plane--Miss G. D. Sadd: Certain Types
of Plane Unicursal Curves.-H. M. Shaffer:' The General Theory of Plane Unicursal Curves.-H. M. Shaffer:' The General Theory of Notational Relativity.-Pundit Oudh Upadhyaya: (1) Note on Forms.-J. R. Wilton: Gibbs's Phenomenon in Fourier's Series and Integrals.

Institution of Mining and Metallorgt (at Geological Society), at 5.30.-Discussion on Paper by H. F. Collins: The Igneous Rocks of the Province of Huelva and the Genesis of the Pyritic Orebodies.-A. V. Reis: Underground Working of Wide Pyritic Orebodies.

Royal Aeronavtical Society (at Royal Society of Arts), at 5.30.-Capt. F. M. Green: Development of the Fighting Aeroplane.

Societr of ARChitects, at 6.
CHILD STUdY Societr (at Royal Sanitary Institute), at 6.-Miss von Wyss: Vital Elements in Art Teaching.

von Wyss: Vital Elements in Art Teaching.
Instimntion of Flectrical FingineErs, at 6.-L. H. A. Carr: Induotion-type Synchronous Motors.
tyon

tion-type Synchronous Motors.
Concrete Institure, at 7.30.-E. F. Sargeant: (a) The Preparation of Concrete Aggregates; (b) Moving Forms.

Chemical Societr, at 8.-G. T. Morgan and J. D. Main Smith : Researches on Residual Affinity and Co-ordination. Part VII., Cobaltic Lakes of the Alizarin Series.

Institution of Atromobile Engineriss (London Graduates' Meeting), at 8.-E. Chatterton: The Design of Automobile Clutches. Campra Club, at 8.15.-F. F. Renwick: The Action of Dyes in Colour Sensitising and Desensitising Drr Plates.

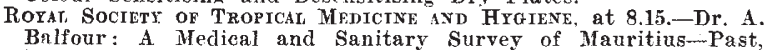
Present, and Future.

Society of Axtrquaries, at 8.30 .

FRIDAY, DECEMBER 16

INSTITute of TRANSPORT (at Royal Society of Arts), at 5.-J. Paterson: The Operation of a Road Distributing Agency.

Institution of Mechanical Engineers, at $6 .-\mathrm{G}$. Mitchell : Conveying and Flevating Machinery-R. F. Knight: Discharge of Grain Cargoes in the Port of London by Pneumatic Elevators.

JuNior Institrition of Enginfers, at 8.-A. J. Simpson: Notes on Searchlight Construction and Operation.

Royal Photographic Soctety of Great Britain (Pictorial Group), at 8.-I. Richmond: Address.

\section{SATURDAY, DECFMBER 17}

Physiological Society (at London Hospital), at 4-H. E. Roaf (i) The Relation of Plant Pigments to Urinary Pigmentation : (ii) A Useful Modification of the Induction Coil ; (iii) The Acidity of Muscle during Maintained Contraction.-W. A. M. Smart and H. F. Roaf: 'The Relation of Methæmoglobin to Oxyhæmoglobin. H. W. Roaf: The Relation of Methæmoglobin to Oxyhæmoglobin. A New Drop-recorder.-H. E. Roaf: A Simple Method for the A New Drop-recorder.-H. E. Roaf: A Simple Method for the Detection of Nitrogen in Physiological Fluids.-G. Williamson:
Note on the Resonator System in the Cochlea, with a Model.Note on the Resonator System in the Cochlea, with a Model,-
T. Lewis, A. N. Drury. C. C. Ilieseu, and A. M. Wedd: The Action of Quinidine on the Mammalian Auriate-F. C. Dodds and T. McIntosh: Changes in the $\mathrm{CO}_{2}$ Content of Whole Blood and Plasma produced by Meals.-V. H. Mottram: Growth of Cats on Various Pure and Mixed Fats-H. Hártridge: Vindication of the Resonance Theory of Hearino.-D. T. Barry: Spontaneous Rhythmic Contractions of Flexor Type in the Dog's Hind Iimb. Postural Influence, etc.

MONDAY, DECEMBER 19.

Institction of Mechanicat Fingineens (Graduates' Meeting), at 7 ... C. Poole : Worm-gearing.

Aristotelian Society (at University Club. 21 Gower Street, W.C.1), at 8.-F. Tavani: Physical Space and Hvperspaces.

Roral INstitute of BRITsSH ARCHitects, at 8.

TUESDAY, DECEMBER 20.

Royal Society of MeDicrive, at 5.-General Meeting.

RoYal Statistical Societr (at Roval Snciety of Arts), at 5.15.E. A. Rusher: Statistics of Industrial Morbidity in Great Britain : A Retrospect and a seheme of Development.

Royal Photographic Socifty of Grmat Britaty, at $7 .-\mathrm{C}$. R. C. Petley : The Chamonix Valley (Lantern Meeting).

Royal Geographical Societr (jointly with the Alpine Club) (at Queen's Hall), at 8.30.-Lieut.-Col. O. K. Howard-Bury, G. I. Mallory, and other Members of the Expedition: The Mount
Everest Expedition.

No. 2720 , VOL. IO 87
WEDNESDAY, DECEMBER 21

RoYal Societr of Medicine (History of Medicine Section), at 5.O. J. S. Thompson: The Parturition Chairs-their History and Use.-Miss Eileen Power: An English Woman poctor in the Fifteenth Century.

Rotal Meteorological Societr, at 5 .

GEOLOGICAL SOCIETY OF LONDON, at 5.30.-L. Owen: Notes on the Phosphate Deposit of Ocean Island, with Remarks on the Phosphates of the Equatorial Belt of the Pacific Ocean-H. B. Milner: The Nature and Origin of the Pliocene Deposits of the County of Cornwall, and their Bearing on the Pliocene Geology of the South-West of England.

Royal MICROSCOPICAL Societr, at 8.-E. A. Smith: The Microscope in Non-ferm.. Metallurgical Research.-Dr. J. G. Parker and Dr. S. H. Browning: The Practical Value of the Microscope in Dr. S. H. Browning: The Practical Val
Connection with Leather Manufacture.

\section{PUBLIC LECTURES.}

(A number in brackets indicates the number of a lecture in a series.)

THURSDAY, DECEMBER 15.

Royal College of SuRgens, at 4.-F. W. Twort: Regent Researches on the Biology of Bacteria (Brown Lecture) (3).

University College, at 5.-Prof. J. E. G. De Montmorency : Religion and Feudalism (7).

LEPLAY HotSE, 65 Belgrave Road, S.W.1, at 8.15.-Dr. C. W. Saleeby: Light against Death.

MONDAY, DECEMBER 19

Rotal College of Surgeons, at 4.-F. W. Twort: Recent Researches on the Biology of Bacteria (Brown Lecture) (4)

KING's College, at 5.30.-Dr. W. R. Ormandy: Liquid Fuel Engines (5).

TUESDAY, DECEMBER 20.

Rotal Collfeg of Scrgeons, at 4.-F. W. Twort: Recent Researches on the Biology of Bacteria (Brown Lecture) (5),

King's Coltege, at 5.30.-Dr. W. Brown: Psychology and Psychotherapy $(10)$

WEDNESDAY, DECEMBER 21.

School of Orifntal Stcdies, at 12,-Miss Alice Werner: Bantu Tribes of East Africa (6).

\section{CONTENTS.}

PAGE

The Research Department . . . . . . . . . 489

Gas Warfare. By S. J. M. A. . . . . . . . . 492 Zoology for Medical Students . . . . 493 The Study of Rocks. By Dr. J. W. Evans, F.R.S. 494 Our Bookshelf

Letters to the Editor:-

The Action of Sunlight.-Sir Oliver Lodge, F. R. S. 496

Microscope Illumination and Fatigue. - $\mathbf{H}$. J. Denham

Tin Plague and Scott's Antarctic Expedition.-Prof. Alan W. C. Menzies . . . 496

The Dispersal of Snails by Birds.-Prof. T. D. A. Cockerell.

The Distribution of Brightness in the Penumbra during an Eclipse of the Moon. (With Diagrams.) F. J. W. Whipple

Awards to Discoverers W Walter B Priest * 497

The Smoke-veil.-Dr. W. Lawrence Balls: . 499

An Oyster Spat (192I) with Mature Male Sexual Products.-Dr. J. H. Orton

The Flight of Thistledown. Prof. James Smail. 500 The Study of Agricultural Economics. By C. $\mathbf{S}$.

Orwin . . . . . . . . . . . . . 501 Black Coral as a Charm for Rheumatism. By Prof.

J. Stanley Gardiner, F.R.S. . . . . . . . 505 Obituary:-

J. M. Dodds. By J. H. G. . . . . . . . . 506

\section{Notes}

Our Astronomical Column :-

Fireballs

Observers' Handbook, ig22 (British Astronomical Association)

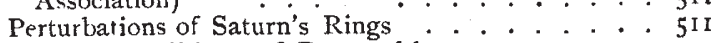

The Mound-builders of Dunstable... . . . 512

Norwegian Meteorology. By J. W. . . . . 512 The Preservation of our Fauna. By $\dot{\mathrm{T}}$. A. Coward $5 \mathrm{I} 3$ Researches on Food . . . . . . . . . . . . 513 University and Educational Intelligence... . . 514 Calendar of Scientific Pioneers ......... 515 Societies and Academies . . . . . . . . . . 515 Books Received . . . . . . . . . . . 518

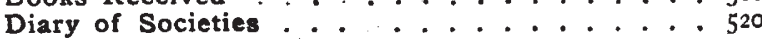

